\title{
Development of Self-Change Classical Guidance Module to Reduce Student's Stress Due to COVID-19
}

\author{
Hendro Wahyudi ${ }^{\left.1^{*}\right)}$, I Ketut Dharsana ${ }^{2}$, Kadek Suranata $^{3}$ \\ 1,2,3 Universitas Pendidikan Ganesha \\ *Corresponding author, e-mail: hndro86@yahoo.com
}

Received August 02, 2021; Revised August 31, 2021; Accepted Sept. 20, 2021; Published Online 2021-10-01

\section{Conflict of Interest} Disclosures:

The authors declare that they have no significant competing financial, professional or personal interests that might have influenced the performance or presentation of the work described in this manuscript.

\begin{abstract}
The COVID-19 pandemic is affecting to the learning process in school. As an effort to reduce the spread of virus, all of learning activity now conducted via online. Various obstacles arise during the online learning. This new condition increases the level of student's stress and requires students ready to make self-change. This study is research and development that aims to develop and evaluate the classical guidance module as an instrument to help students make self-change in order to reduce their stress. The development procedure conducted by following 4D model (Thiagarajan, 1974). Five experts involved as judges to evaluate the content validity of module and 30 students were involved as subject on piloting study. Results of expert judgement were analyzed using formula Lawshe and show the module has a "very special" content validity index $(\mathrm{CVI}=1)$. Results of piloting study show the module has "very good" category in all aspect of evaluation. Based on the results, it shows that the classical guidance module developed in this study feasible to use as an instrument to help students make self-change in order to reduce their stress levels due to COVID-19.
\end{abstract}

Keywords: Student's academic stress, classical guidance, self-change.

\section{Introduction}

The corona virus and disease (COVID) pandemic since the end of 2019 has changed the world order in various sectors. The COVID-19 pandemic is changing the order of social life, one of which is a process (Strielkowski, 2020). The learning process which was initially carried out face-to-face, during this pandemic must follow the government's instructions, namely during the period to prevent the transmission of the COVID-19 virus. Some of the advantages of learning during are that it makes teaching and learning activities more accessible from various times and places (Shukla, Dosaya, Nirban \& Vavilala, 2020). The use of media during also allows students to get wider information through the internet. The use of this technology is considered very helpful in carrying out learning during social restrictions during the COVID-19 pandemic 
(Pakpahan \& Fitriani, 2020). In addition to the advantages of learning during, there are also various obstacles that arise in its application. Learning through the internet has become a difficult thing to do in certain areas with inadequate networks. Constraints that are also faced by students such as internet packages that run out, homework that must be done too and college assignments that pile up. Various academic demands that must be completed by students cause them to experience academic stress. The inability of students to adapt to these new circumstances makes them experience academic stress (Hastini et al, 2020).

According to Szalavitz (2011) the incidence of stress in students in the world is $38-71 \%$. Taufik \& Ifdil's research (2013) states that the level of academic stress of students in the city of Padang belongs to the category of moderate academic stress level, which is $71.8 \%$. Meanwhile $13.2 \%$ are at high academic stress levels and $15 \%$ of students in Padang city are at low academic stress levels. Based on the results of a survey conducted by Kompas Research and Development, as many as $28.3 \%$ of students experience stress if this system lasts a long time (Mediana, 2020). Then, the Indonesian Child Protection Commission (KPAI) received a report that $79.9 \%$ of students did not like learning from home because $76.8 \%$ of teachers did not interact other than giving assignments (Fakhri, 2020). Through these data, it can be seen that the online learning system causes the potential for stress to increase in students, especially high school students at the end of the year. This is in accordance with the statement of Burzynska \& Contreras (2020) which states that the end of the school term is measured as potential stress because students are in a phase of anxiety determining careers or majors in college. And stress increases because they have to try to adjust to their physical and emotional changes (Raharjo \& Sari, 2020).

This new condition requires students to make self-change. Dharsana (2015) states that self-change is the need to make changes including something new, seeking new experiences, and changing them every day. These changes will form a new behavior. The environment is also important in shaping and maintaining behavior where the behavior does not stand alone in the environment to produce consequences, but is also controlled by other consequences. There are three elements that must be specified in the description of the interaction between an organism and the environment, namely the opportunity for a response to occur, the response itself and the reinforcing consequences. This is what can prevent academic stress on students (Dharsana, 2015).

According to Skinner (in Dharsana, 2015) behaviorism or behavior, there is no predictable response / control only the probability of a similar response that may be produced to produce a response or result. The self is developed by environmental history and is maintained or eliminated by current reinforcing contingencies. Environmental contingencies determine how people perceive and know and the environment also shapes consciousness which is a social production. Dharsana (2015) stated by allowing new habits to develop in the same situation, old habits may disappear. The term "reciprocal inhibition" includes all situations in which withdrawal of a response causes a reduction in the strength of a response causing a reduction in strength simultaneously. For example, a response that is antagonistic (contrary to) anxiety can be made to occur by presenting a stimulus that causes anxiety / stress so that there is complete or partial suppression as a result of the bond between the stimulus and the anxiety / stress response will be weakened. With students who have high self-change abilities, it will be very easy for students to adapt to changes and new environments, so they will be free from stress. This study aims to overcome academic stress through the development of modules that can be used as guidelines by students in preventing academic stress.

\section{Method}

\section{Research Design}

This study is research and development $(\mathrm{R} \& \mathrm{D})$ that conducted by following the 4D model (Thiagarajan, 1974) that consist four stages of development namely (1) define, (2) design, (3) develop, and (4) disseminate.

\section{Research Subject}

This study involved 3 expert and 2 practitioners in guidance and counseling field as judges to evaluate the content validity of module. 30 students also involved as subject in piloting study to evaluate the acceptance of module.

\section{Data Analysis}

The method of data collection in this research is use the expert judgment validation questionnaire to evaluate the content validity and student's acceptance questionnaire to collect data about student's responses 
in piloting study. Analysis of the expert judgements results conducted using formula Lawshe (1975). Students response to acceptance questionnaire were analyzed qualitative.

\section{Results and Discussion}

The development process in this study conducted in four stages as describe in table 01 below.

Table 01. Self-change Classical Guidance Module Development Process

\begin{tabular}{|c|c|c|c|c|c|}
\hline No & Stage & Source & Data & Tehnikal & Instrumen \\
\hline 1 & $\begin{array}{l}\text { Preliminary } \\
\text { Study } \\
\text { Student }\end{array}$ & Student & $\begin{array}{l}\text { psycho test activities: } \\
\text { Intelligence, verbal } \\
\text { talent, numerical } \\
\text { talent, abstract talent, } \\
\text { spatial relation talent, } \\
\text { personality mechanic }\end{array}$ & $\begin{array}{l}\text { talent } \\
\text { Observation } \\
\text { Interview }\end{array}$ & Kuesioner \\
\hline 2 & Product Design & $\begin{array}{c}\text { Supervising } \\
\text { lecturer }\end{array}$ & $\begin{array}{l}\text { Draft I product } \\
\text { module development } \\
\text { and supervisor revision }\end{array}$ & & $\begin{array}{c}\text { Product design } \\
\text { pattern }\end{array}$ \\
\hline 3 & $\begin{array}{l}\text { Design } \\
\text { Validation }\end{array}$ & Validator & $\begin{array}{l}\text { Draft I product } \\
\text { module development } \\
\text { and supervisor revision } \\
\text { Product validation } \\
\text { sheet }\end{array}$ & & $\begin{array}{l}\text { Revision } \\
\text { Product } \\
\text { validation } \\
\text { sheet }\end{array}$ \\
\hline 4 & Limited Trial & & $\begin{array}{l}\text { 1. Cognitive } \\
\text { assessment } \\
\text { 2. Psychomotor } \\
\text { assessment } \\
\text { 3. Affective assessment } \\
\text { 4. Student response }\end{array}$ & & $\begin{array}{l}\text { Limited trial } \\
\text { revision }\end{array}$ \\
\hline
\end{tabular}

The appearance of self-change classical guidance module shows below.
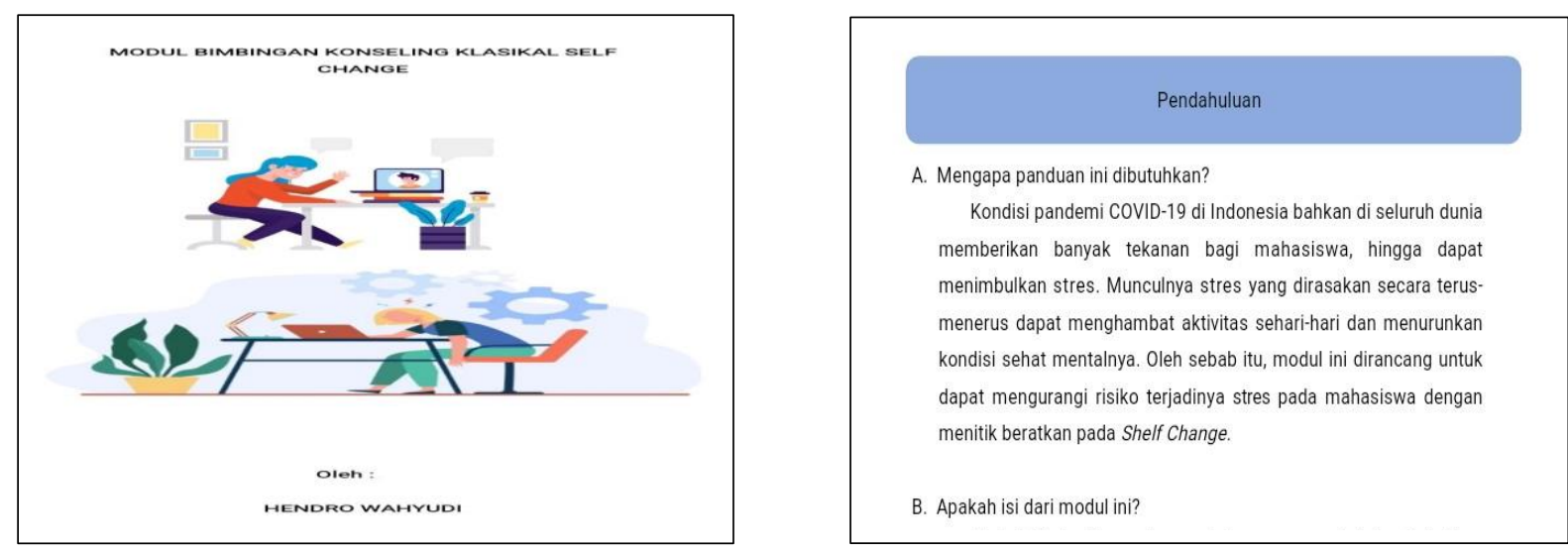

Figure 01. The Design of Self-change Classical Guidance Module

Figure with permission (CWahyudi, dkk. 2021 
The results of expert judgments to the content validity of module were analyzed using formula Lawshe (1975). The content validity ratio analysis describe below.

Table 02. Results of Expert Judgments

\begin{tabular}{|c|c|c|c|c|c|c|c|c|}
\hline \multirow[t]{2}{*}{ No } & \multicolumn{5}{|c|}{ Expert Judgment } & \multirow{2}{*}{$\begin{array}{l}\text { Amount of } \\
\text { Approvals }\end{array}$} & \multirow[t]{2}{*}{ CVR } & \multirow{2}{*}{$\begin{array}{l}\text { Status } \\
\text { Item }\end{array}$} \\
\hline & Expert & Expert & Expert & Expert & Expert & & & \\
\hline & 1 & 2 & 3 & 4 & 5 & & & \\
\hline 1 & 3 & 3 & 3 & 3 & 3 & 15 & 1 & Accepted \\
\hline 2 & 3 & 3 & 3 & 3 & 3 & 15 & 1 & Accepted \\
\hline 3 & 3 & 3 & 3 & 3 & 3 & 15 & 1 & Accepted \\
\hline 4 & 3 & 3 & 3 & 3 & 3 & 15 & 1 & Accepted \\
\hline 5 & 3 & 3 & 3 & 3 & 3 & 15 & 1 & Accepted \\
\hline 6 & 3 & 3 & 3 & 3 & 3 & 15 & 1 & Accepted \\
\hline 7 & 3 & 3 & 3 & 3 & 3 & 15 & 1 & Accepted \\
\hline 8 & 3 & 3 & 3 & 3 & 3 & 15 & 1 & Accepted \\
\hline 9 & 3 & 3 & 3 & 3 & 3 & 15 & 1 & Accepted \\
\hline 10 & 3 & 3 & 3 & 3 & 3 & 15 & 1 & Accepted \\
\hline 11 & 3 & 3 & 3 & 3 & 3 & 15 & 1 & Accepted \\
\hline 12 & 3 & 3 & 3 & 3 & 3 & 15 & 1 & Accepted \\
\hline 13 & 3 & 3 & 3 & 3 & 3 & 15 & 1 & Accepted \\
\hline 14 & 3 & 3 & 3 & 3 & 3 & 15 & 1 & Accepted \\
\hline 15 & 3 & 3 & 3 & 3 & 3 & 15 & 1 & Accepted \\
\hline 16 & 3 & 3 & 3 & 3 & 3 & 15 & 1 & Accepted \\
\hline 17 & 3 & 3 & 3 & 3 & 3 & 15 & 1 & Accepted \\
\hline 18 & 3 & 3 & 3 & 3 & 3 & 15 & 1 & Accepted \\
\hline 19 & 3 & 3 & 3 & 3 & 3 & 15 & 1 & Accepted \\
\hline 20 & 3 & 3 & 3 & 3 & 3 & 15 & 1 & Accepted \\
\hline 21 & 3 & 3 & 3 & 3 & 3 & 15 & 1 & Accepted \\
\hline 22 & 3 & 3 & 3 & 3 & 3 & 15 & 1 & Accepted \\
\hline 23 & 3 & 3 & 3 & 3 & 3 & 15 & 1 & Accepted \\
\hline 24 & 3 & 3 & 3 & 3 & 3 & 15 & 1 & Accepted \\
\hline 25 & 3 & 3 & 3 & 3 & 3 & 15 & 1 & Accepted \\
\hline
\end{tabular}

The CVR analysis show total CVR result $=25$ which means that the item were valid. After obtaining the CVR, then continue by calculating content validity ratio following formula Lawshe below.

$$
\begin{gathered}
C V I=\frac{\sum C V R}{K} \\
=\frac{25}{25}=1
\end{gathered}
$$

Based on the CVI analysis it show the number of content validity of module is 1 that category in "very special" content validity index.

The results of students responses in module limited trial show below. 
Table 03. Student's Responses on Module Limited Trials

\begin{tabular}{lll}
\hline No. & \multicolumn{1}{c}{ Activity } \\
& \\
\hline 1 & Trial Modul I & $\begin{array}{l}\text { 1. There are statements that confuse students } \\
\text { 2. Adding interesting pictures according to the topic } \\
\text { 3. Students need direction to draw conclusions }\end{array}$ \\
& Trial Modul II & $\begin{array}{l}\text { 1. There are several terms that confuse students } \\
\text { 2. Adding interesting pictures according to the topic } \\
\text { 3. There are some writings that are not neatly typed on page } 7\end{array}$ \\
\hline
\end{tabular}

Based on suggestions and input on the module trial, the module has been improved based on input from students. After the revisions, the module then disseminates to students to evaluate the acceptance. The results of product dissemination are described below.

Table 04. The Results of Module Acceptances

\begin{tabular}{lccc}
\hline No. & Aspect & Average & Kategory \\
\hline 1 & Module Title & 4,00 & Very Good \\
2 & Module Contents & 3,933 & Very Good \\
3 & Serving Method & 4,00 & Very Good \\
4 & Language & 4,00 & Very Good \\
5 & Completeness & 4,00 & Very Good \\
6 & Utility & 4,00 & Very Good \\
7 & Execution & 3,50 & Very Good \\
& Overall aspect average & $\mathbf{3 , 9 2}$ & Very Good
\end{tabular}

Based on the results of the questionnaire at the dissemination and implementation stages, an average of 4.00 was obtained for the module title aspect, module content aspect 3.933, presentation method aspect 4.00 , language aspect 4.00 , completeness aspect 4.00 , usability aspect 4.00 and aspects of implementation 3.50 . The average of all aspects is categorized as "very good", so the self-change module for dealing with academic stress due to the COVID-19 pandemic is very good to implement

\section{Discussion}

Self-change classical guidance is a guidance and counseling service between competent counselors and counselees jointly carried out in group settings to get solutions to the problems they face by helping group members to achieve their development goals. The results of this study indicate that based on the assessment conducted by 5 experts and practitioners in the field of counseling guidance, the self-change BK module developed has a special content validity index. Of the 25 instrument items used to assess content validity, the developed module has good validity for all items. Assessment of the content validity index of the classical self-change counseling guidance module is one of the important stages in the development of counseling guidance service tools. This assessment is important to do with the aim that before being used to provide services to students, the modules developed have met the theoretical feasibility.

Based on the results of the analysis of the expert validity of the product, the classical self-change counseling guidance module is very important to be developed, on the basis of the results of the content validity analysis by experts obtaining an agreement between the assessors regarding the importance of the guide module product items. The results of the above data analysis using the formula Lawshe CVR test obtained a per-item value $(C V R>0)$ and there were no items with a value less than $0(C V R<0)$. Furthermore, the results of the Lawshe CVI analysis obtained a score of 1, then the number was declared eligible or 
accepted. From the empirical test the results of the number of instruments are 25 items, it is found that all items are declared valid. The reliability test according to $\mathrm{R}_{\text {hit }}$ got a value of 0.941 , which is greater than the $\mathrm{R}_{\mathrm{tab}}$ criterion of 0.06 , so it is declared valid or accepted.

\section{Conclusion}

The results of expert judgments to evaluate the content validity of module developed ind this study show that the module has a "very special" content validity index. Based on the students responses on the module limited trial, it show that the module has "very good" category in all aspect of acceptance evaluation. Based on the results, it can conclude that the classical guidance module developed in this study has meet the criteria of good instrument to help. This study has implication to the development of guidance and counseling service, especially to help students reducing their stress level due to COVID-19.

\section{Acknowledgment}

This research written to fulfill one of the requirements to obtain a Master of Education degree in Counseling Guidance Study Program in Universitas Pendidikan Ganesha. The completion of this study has received a lot of help from various parties. May all the help they have given in completing this study, blessed with commensurate rewards by God Almighty, health, and harmony in living life. The author realizes that this thesis is not perfect, but its presence in the constellation of the academic community will add to the treasury of knowledge in the development of science. Hopefully this reserach will be useful for the academic community.

\section{References}

Budu, H. I., Abalo, E. M., Bam, V., Budu, F. A., \& Peprah, P. (2019). A survey of the genesis of stress and its effect on the academic performance of midwifery students in a college in Ghana. Midwifery, 73, 69- 77. https://doi.org/10.1016/j.midw.2019.02.013.

Chaterine, R. N. (2020, March 18). Siswa belajar dari rumah, KPAI: Anak-anak stres dikasih banyak tugas.Detik News. Retrieved from https://news.detik.com/berita/d-4944071/siswa-belajar-darirumah-kpai-anak-anak-stres-dikasih-banyak-tugas.

Corey, Gerald, 2015, Teori Dan Praktek Konseling Dan Psikoterapi, Cet VII, (Bandung: Refika Aditama).

Desmita. (2010). Psikologi Perkembangan Peserta Didik. Bandung: Remaja Rosdakarya.

Dharsana, I Ketut. (n.d.). Pengembangan pribadi konselor (2018th ed.). BK FIP UNDHIKSA.

Dharsana, I Ketut. (2015b). RPBK untuk pengembangan variabel terikat bakat (05 juni 2015). BK FIP UNDHIKSA.

Dharsana, I Ketut. (2015c). RPBK untuk pengembangan variabel terikat minat-1. BK FIP UNDHIKSA.

Dharsana, I Ketut. (2015d). RPBK untuk pengembangan variabel terikat self -3 (2015th ed.). BK FIP UNDHIKSA.

Hastini, L. Y., Fahmi, R., \& Lukito, H. (2020). Apakah pembelajaran menggunakan teknologi dapat meningkatkan literasi manusia pada generasi $\mathrm{Z}$ di Indonesia ? Jurnal Manajemen Informatika (JAMIKA), 10(1), 12-28.

Hughes, R.G (2008). Patient Safety and Quality: an evidence base handbook for nurses.Rochville MD: Agency for Healthcare Reseach and Quality Publication

Kementrian Kesehatan. (2020). Situasi Terkini Perkembangan Coronavirus Disease (COVID-19) https://covid19.kemkes.go.id/situasi-infeksi-emerging/info-corona-virus/situasi-terkiniperkembangan-coronavirus-disease-covid-19-31-mei-2020/\#.XtRqYb4xWNw

Lawshe,C. H.. (1975). A Quantitive Approach to Content Validity. Purdue University: Personnel Psychology, Inc. Hlm. 563-575.

Muharrifah, A. 2009. Interaksi antara Remaja, Ayah, dan Sekolah Serta Hubungannya dengan Tingkat Stres dalam Menghadapi Ujian Nasional(Doctoral dissertation). 
M. C., Brunello, N., \& Tascedda, F. (2019). Modulation of neuroplasticity-related targets following stressinduced acute escape deficit. Behavioural Brain Research, 364, 140-148. https://doi.org/10.1016/j.bbr.2019.02.023

Pat Walker Health Center, University of Arkansas. (n.d.). COVID-19 workshop: How to manage your anxiety effectively. https://health.uark.edu/coronavirus/caps-covid-19-resources-anxietyworkbook.pdf

Strielkowski, W. (2020). COVID-19 recovery strategy for tourism industry COVID-19 recovery strategy for tourism industry. March, 1-3. https://doi.org/10.13140/RG.2.2.19039.82086

Sugiyono. (2018). Metode Penelitian Kuantitatif Kualitatif dan R\&B. Bandung: Alfabeta.

Szalavitz, M. (2011).“Tapping Potential: Stand and Deliver”.Psychology Today.50-54.

Article Information (Supplementary)

\section{Conflict of Interest Disclosures:}

The authors declare that they have no significant competing financial, professional or personal interests that might have influenced the performance or presentation of the work described in this manuscript.

Copyrights Holder: <wahyudi $><2021>$

First Publication Right: BISMA The Journal of Counseling

https://doi.org/10.xxxx/ $\mathbf{x x x x x}$

Open Access Article | CC-BY Creative Commons Attribution 4.0 International License.

Word Count: 